\title{
Immunogenicity of a commercial Salmonella enteritidis vaccine in layer birds
}

\author{
F. Nasrin ${ }^{1,2 *}$, M. S. R. Khan ${ }^{1}$ and M. A. Islam ${ }^{1}$ \\ ${ }^{1}$ Department of Microbiology and Hygiene, Faculty of Veterinary Science, Bangladesh Agricultural \\ University, Mymensingh-2202 \\ ${ }^{2}$ Department of Livestock Services, Ministry of Fisheries and Livestock, Dhaka, Bangladesh
}

\begin{abstract}
Background

The aged birds are known to induce good immunity against Salmonella enteritidis as compared to young. To judge this hypothesis layer birds at 42 and 49 days old were vaccinated with AVI Pro®109SE4 vaccine and immune response in terms of antibody titers was measured.
\end{abstract}

\section{Methods}

A composition of antibody production in vaccinated chicken was performed following a usual vaccination schedule with a newly suggested vaccination schedule. To study the immunogenicity of vaccine a total of 15 chickenswere divided into three groups. Each group comprised of 5 layer chicken. Chicken in group A and B were vaccinated with AVI Pro®109SE4 vaccine with a dose of $0.5 \mathrm{ml} /$ bird through SC route. Primary vaccination was performed at 42 days and 49 days of age respectively and booster vaccination was given at 72 days and 79 days of age respectively. Blood samples were collected to obtain sera from each chicken at every 7 days interval up to 93 days post vaccination for the determination of antibody titer using microplate agglutination test.

\section{Results}

Highest mean antibody titers were recorded as $179.20 \pm 70.11$ and $307.20 \pm 114.49$ in birds of group $\mathrm{A}$ and B respectively. The highest mean antibody titer was recorded as $307.20 \pm 114.49$ in chicken at 21 days post vaccination with AVI Pro®109SE4 vaccine using newly suggested schedule as compared to usual schedule of vaccination.

\section{Conclusions}

Primary vaccination at birds at 49 days (newly planned vaccination schedule) of age induced better immune response as compared to birds vaccinated at 42 days of age.

Key words: Immunogenicity, Salmonella enteritidis, vaccine, chicken

*Correspondence: fouziaidita@gmail.com

All right reserved 0429/2018

Copyright (C) 2018 Bangladesh Society for Veterinary Medicine. This is an open access article under the CC BY license (http://creativecommons.org/licenses/by/4.0/), which permits unrestricted use, distribution, and reproduction in any medium, provided the original author and source are credited. 


\section{Introduction}

Salmonella. enteriditisis is a rod-shaped, Gramnegative, non-spore forming, predominantly motile enterobacteria with diameters around 0.7 to $1.5 \mu \mathrm{m}$, lengths from 2 to $5 \mu \mathrm{m}$.Salmonella are closely related to the Escherichia genus and are found worldwide in warm and cold-blooded animals, in humans, and in non living habitats (Pomeroy, 1978).Salmonella enteric consists of over 2,000 serovars that are major causes of morbidity and mortality associated with contaminated food. Despite similarities among serovars of Salmonella enterica, many unique host specificities, epidemiological characteristics, and clinical manifestations. One of the unique, epidemiological characteristics of the serovar enteritidis is that it is the only bacterium routinely transmitted to humans through intact chicken eggs. Therefore, Salmonella enteric serovar enteritidis must be able to persist chicken eggs to be transmitted to humans, and its survival in egg is important for its transmission to the human population. The ability of Salmonella enteric serovar enteritidis to survive in and transmitthrough eggs may have contributed to its drastically increased prevalence in the 1980s and 1990s. Salmonella enteric serovar enteritidis can persist in egg albumen (Raul et al., 2005).The basis for the successful control of salmonella infections in poultry farms is good farming and hygiene practices and the testing and removal of positive flocks from production (Calnek et al., 1997). Vaccination of chickens is regarded as an additional measure to increase the resistance of birds against the salmonella exposure and decrease shading of Salmonella. Vaccination against $S$. enteritidis protects chickens from infection or re-infection through vermin and the environment, infection from contaminated feed, spread of an undetected infection, spread of infection in the hatchery, mainly in the hatchers and spread of infection in a flock where a few chickens are not protected. The offspring of vaccinated birds are protected by maternal antibodies. When the parent birds are vaccinated against salmonella, the chicks are protected by maternal antibodies in the hatchery. This will limit the spread of infection in the hatchery.

The costs or impracticality of improvements in hygienic and management together with increasing problems of antibiotic resistance indicates that vaccination in poultry will become more attractive as an adjunct to existing control measures (Zhang-Barber et al., 1999). Vaccination of chickens is regarded as a measure to increase the resistance of birds against Salmonella exposure and decrease the shedding. There is experimental and some field evidence that a reduced level of fecal excretion and systemic invasion of normal Salmonella organisms in vaccinated birds will result a reduced contamination of table eggs and the environment. In Bangladesh both live and killed vaccines are available, which are imported and marketed by commercial companies. However, none of the vaccine has report to judge its potency trial experiment in chickens under field condition in Bangladesh. It is believed that aged birds are known to induce good immunity against S. enteritidis as compared to young. The present work was designed to study the immunogenicity of commercially available AVI Pro®109 SE4 vaccine used to prevent $S$. enteritidis infection.

\section{Materials and methods}

The study was carried out in the Department of Microbiology and Hygiene. Bangladesh Agricultural University (BAU), Mymensingh, 2202, Bangladesh, during the period from May 2009 to May 2010.

\section{Chemicals and reagents}

The reagents used during the study were phosphate buffered saline (PBS), Physiological saline, $10 \%$ formalin, alcohol and safranin.

\section{Experimental chickens}

A total of 15 chickens of 42 days old (Hisex White) were collected from the Phenix Hatchery Ltd, Member Bari, Gazipur. These chicks were housed in the poultry shed of the Department of Microbiology and Hygiene, BAU, Mymensingh. The birds were provided with nutrient diet, pure water, fresh litter and reared under strict biosecurity.

\section{AVIPro®109 SE4 Vaccine}

Inactivated AVIPro®109 SE4 vaccine marketed by ACI Ltd Bangladesh was used in this experiment. The vaccine was purchased from the local market and stored at $4-8^{\circ} \mathrm{C}$ until use. 


\section{Salmonella enteritidis isolate}

A local isolate of S.enteritidis was obtained from the laboratory repository of Department of Microbiology and Hygiene, BAU, Mymensingh and was maintained as a stock to use as antigen in the agglutination test.

\section{Brief description of the experimental design}

The experiment was undertaken to study the immunogenicity of vaccine marketed by ACI Ltd., Bangladesh. A flock of 15 apparently healthy layer birds were used for this experiment. Blood was collected before vaccination to determine pre-vaccination antibody titer. The chicks were then divides into 3 groups such as A, $\mathrm{B}$ and $\mathrm{C}$ each group consisting of 5 birds. Chicken of group A and B were used for experimental immunization and group $\mathrm{C}$ was maintained as unvaccinated control. The birds of group A was vaccinated with AVIPro®109 SE4 according to the manufacturer's instruction. Birds of group B was vaccinated with newly suggested schedule. To determine the antibody response against the vaccine used, blood samples of the birds of each vaccinated group were collected at every 7 days interval up to 28 days of $2^{\text {nd }}$ vaccination. Sera were prepared to determine the antibody titer by microplate agglutination test and to compare the titer.

\section{Experimental immunization}

The experimental immunization of chickens of layer breed was performed by inactivated AVIPro®109 SE4 vaccine. Vaccination was carried out following usual schedule recommended by the manufacturers and a newly suggested schedule. Vaccine was administered through SC route and at the dose of $0.5 \mathrm{ml}$ for each bird.

\section{Vaccination Schedule}

Experimental chickens were divided into three groups such as $\mathrm{A}, \mathrm{B}$ and $\mathrm{C}$ each consisting of 5 birds. The chickens of group A and B were vaccinated with AVIPro®109 SE4 vaccine imported by ACI Ltd, Bangladesh following usual recommended schedule and a newly suggested schedule. The initial dose $(0.5 \mathrm{ml})$ of vaccine was administered to the chickens in group A through SC route at the age of 42 days (6 weeks) and to the chickens in group B at the age of 49 days (7 weeks) through sc route. The chickens of group A and B were revaccinated with same dose of vaccine through SC route after 30 days of primary vaccination as booster. Vaccination schedule is presented in Table 1.

Table.1 Vaccination schedule used for immunization of chicken

\begin{tabular}{|c|c|c|c|c|c|c|c|}
\hline \multirow{2}{*}{$\begin{array}{c}\text { Breed of chicken } \\
\text { used for } \\
\text { vaccination }\end{array}$} & \multirow{2}{*}{$\begin{array}{l}\text { Group of } \\
\text { birds }\end{array}$} & \multirow{2}{*}{$\begin{array}{l}\text { Number } \\
\text { of birds }\end{array}$} & \multirow{2}{*}{$\begin{array}{l}\text { Vaccines } \\
\text { used }\end{array}$} & \multicolumn{2}{|c|}{ Age of Vaccination } & \multirow{2}{*}{$\begin{array}{l}\text { Dose of } \\
\text { vaccine / } \\
\text { bird }\end{array}$} & \multirow{2}{*}{$\begin{array}{l}\text { Vaccination } \\
\text { route }\end{array}$} \\
\hline & & & & $1^{\text {st }}$ dose & $2^{\text {nd }}$ dose & & \\
\hline \multirow{2}{*}{$\begin{array}{c}\text { Layer (Hisex } \\
\text { White) }\end{array}$} & A & 5 & $\begin{array}{l}\text { AVIPro®10 } \\
9 \text { SE4 }\end{array}$ & $\begin{array}{c}\text { At } 42 \text { days } \\
\text { of age }\end{array}$ & $\begin{array}{l}\text { At } 72 \text { days of } \\
\text { age ( } 30 \text { days } \\
\left.\text { after } 1^{\text {st }} \text { dose }\right)\end{array}$ & $0.5 \mathrm{ml}$ & $\mathrm{SC}$ \\
\hline & B & 5 & $\begin{array}{l}\text { AVIPro®10 } \\
9 \text { SE4 }\end{array}$ & $\begin{array}{l}\text { At } 49 \text { days } \\
\text { of age }\end{array}$ & $\begin{array}{l}\text { At } 79 \text { days of } \\
\text { age ( } 30 \text { days } \\
\left.\text { after } 1^{\text {st }} \text { dose }\right)\end{array}$ & $0.5 \mathrm{ml}$ & $\mathrm{SC}$ \\
\hline
\end{tabular}

$\mathrm{SC}=$ Subcutaneous

Collection of sera from the immunized birds About $1.5-2 \mathrm{ml}$ of blood samples were collected aseptically without anticoagulant from the jugular vein or wing vein of the vaccinated birds of each group using $3 \mathrm{ml}$ disposable plastic syringe. The blood samples were allowed to clot in the syringe after placing in slanted position at room temperature. After clotting of blood the clot was separated from the wall of the syringe by gentle traction and then placed in the incubator at $37^{\circ} \mathrm{C}$ for one hour for retraction of the clot. The syringes were then placed in the refrigerator for about 4 hours. The serum was collected from the syringe and placed in the sterile centrifuge tube and centrifuged at $1500 \mathrm{rpm}$ for 15 minutes to have more clear serum. The sera were collected into sterilized glass vials with rubber cap. The schedules of sera collection is vaccinated birds shown in Table 2. 
Nasrin and others

Table 2. Schedules of collection of sera from experimental chickens immunized with AVIPro®109 SE4

\begin{tabular}{ccccc}
\hline \multirow{2}{*}{ Group of birds } & \multirow{2}{*}{ Vaccine used } & \multicolumn{2}{c}{ Age of vaccination (day) } & \multirow{2}{*}{$\begin{array}{c}\text { Sera collection at days } \\
\text { post vaccination (DPV) }\end{array}$} \\
\cline { 3 - 4 } & & $1^{\text {st }}$ dose & $2^{\text {nd }}$ dose & \\
\hline A & AVIPro®109 SE4 & 42 & 72 & $7,14,21,28$ \\
B & AVIPro®109 SE4 & 49 & 79 & $7,14,21,28$ \\
\hline
\end{tabular}

\section{Inactivation of collected chicken sera}

The stored serum samples were kept in water bath at $56^{\circ} \mathrm{C}$ for half an hour in order to inactivate complements. This procedure was carried out according the procedure described by Choudhury et al., (1985) After inactivation sera were stored at $-20^{\circ} \mathrm{C}$ until use.

\section{Serological analysis}

The serological analysis was conducted by slide and microplate agglutination tests to determine the antibody response against $S$. enteritidis.

\section{Slide agglutination test}

Slide agglutination test was performed for the determination of the presence of specific antibody against $S$. enteritidis in the serum collected from the blood of chickens immunized with vaccinated with AVIPro®109 SE4. One drop of safranin stained antigen was mixed with one drop of antisera on a clean glass slide and kept at room temperature for two minutes to observe the agglutination reaction. Clumping of cells on the slide will be considered as positive and no clumping indicate the negative result.

\section{Microplate Agglutination Test}

This test was carried out for the determination of antibody titer of sera collected from vaccinated groups of chickens. The test was conducted following the procedure of Schlink et al., (1979).

\section{Preparation of $10 \%$ formalinized PBS}

For preparation of $10 \%$ formalinized PBS, $10 \mathrm{ml}$ of formalin was added to $90 \mathrm{ml}$ of PBS solution and then mixed properly by gentle agitation. This preparation was then stored in a refrigerator at $4^{\circ} \mathrm{C}$ for further use.

\section{Preparation of antigen for microplate agglutination test}

The Salmonella isolate was grown in Selenite broth for 18 hours at $37^{\circ} \mathrm{C}$ and then subjected to heat treatment at $100^{\circ} \mathrm{C}$ for 30 minutes in hot water bath. The treated suspension was centrifuged at $2500 \mathrm{rpm}$ for 15 minutes. The supernatant was removed and the sediment was re-suspended with PBS (pH 7.5) and centrifuged at $2500 \mathrm{rpm}$ for 15 minutes. After final centrifugation, $0.1 \mathrm{ml}$ of sedimented cells was suspended in $10 \mathrm{ml}$ of $10 \%$ formalinized PBS. The suspension was then stored in the refrigerator $\left(0-4^{\circ} \mathrm{C}\right)$ for use as antigen in the microplate agglutination test.

\section{Principle of microplate agglutination test}

When a particulate antigen (in this case $S$. enteritidis) is mixed with homologous antibody in presence of electrolyte (in this case PBS) at a suitable temperature and $\mathrm{pH}$, then clumping of organisms is found.

\section{Procedure of microplate agglutination test}

Two fold serial dilution of heat treated $\left(56^{\circ} \mathrm{C}\right.$ for 30 minutes) serum ranging from $1: 2$ to $1: 2048$ were made in $(\mathrm{PBS})$. Equal volume $(50 \mu \mathrm{l})$ of prepared antigen was added in each well of microtiter plate and mixed thoroughly by micro pipette. The plate was incubated for 2 hours at $37^{\circ} \mathrm{C}$ and then for 18 hours at $4^{\circ} \mathrm{C}$ before the results were recorded. Requisite controls of antigen and antisera were also maintained. Positive agglutinations were recorded on the basis of the gravitation of antigen-antibody clumps at the bottom of the wells in microtiter plate.The test was conducted according to the method described by Schlink et al., (1979). Briefly the procedure of agglutination test is described. An amount of $50 \mu \mathrm{l}$ of PBS was first poured in each well up to $10^{\text {th }}$ vertical row of microtiter plate. Then equal amount of test serum $(50 \mu \mathrm{l})$ was added in each well of the $1^{\text {st }}$ row.Two fold dilutions of serum ranging from $1: 2$ to $1: 2048$ were made by transferring $50 \mu \mathrm{l}$ of the mixture of PBSand test serum from the wells of $1^{\text {st }}$ row to the wells of $2^{\text {nd }}$ row and thus continued 
successively up to the wells of $10^{\text {th }}$ row from where an excess amount of $50 \mu \mathrm{l}$ of the mixturewas poured off.After this a volume of 50 $\mu l$ of prepared antigen was added in each well up to the $10^{\text {th }}$ row. Wells in $11^{\text {th }}$ row were maintained as control containing equal volume of $50 \mu \mathrm{l}$ of prepared antigen suspension and PBS. The content of the wells of the test system and control were mixed gentle by micropipette and then incubated for 2 hours. Agglutination resulting from mixing of test serum and prepared antigen in the test system was observed carefully and the results were recorded.A positive agglutination test was indicated by gravitation of antigen-antibody clumps at the bottom of the wells in microtiter plate. The end point was determined by observing the highest dilution at which cells were agglutinated and the reciprocal of the highest dilution was considered as titer of the serum.

\section{Statistical analysis}

The effect of vaccination on experimental birds in terms of antibody titer was subjected to analysis of geometric mean with standard error. The analysis was performed according to procedures described by Shil and Debnath (1985). The statistical analysis was performed using a statistical software package SPSS version 10.00.

\section{Results}

\section{Slide agglutination test}

In slide agglutination test, the serum of all immunized chicken of group A and B gave positive agglutination reaction with $S$. enteritidis. On the other hand the serum of unvaccinated control chicken in group $\mathrm{C}$ did not agglutinate in slide agglutination test. The results of slide agglutination test is presented in Table 3.

Table 3. Results of slide agglutination test of vaccinated and unvaccinated control chicken

\begin{tabular}{ccccc}
\hline \multirow{2}{*}{ Group of chicken } & $\begin{array}{c}\text { Vaccine used for } \\
\text { immunization }\end{array}$ & Route of vaccination & $\begin{array}{c}\text { After 1 } \\
\text { vaccination }\end{array}$ & $\begin{array}{c}\text { After } 2^{\text {nd }} \\
\text { vaccination }\end{array}$ \\
\hline A $(n=5)$ & AVIPro®109 SE4 & SC & + & + \\
B $(n=5)$ & AVIPro®109 SE4 & SC & + & + \\
C $(n=5)$ & ND & ND & - & - \\
\hline
\end{tabular}

$\mathrm{ND}=$ Not done, $\mathrm{SC}=$ Subcutaneously, $+=$ Agglutination, $-=$ No agglutination

\section{Microplate agglutination test}

Microplate agglutination test was conducted to determine the titer of test serum samples collected from the vaccinated and unvaccinated birds used in this study.

\section{Microplate agglutination test of the sera of} chicken belonged to group $\mathrm{A}$

Five layer chicken of this group were immunized with AVIPro®109 SE4 vaccine following usual schedule $0.5 \mathrm{ml}$ of vaccine was administered to the chicken through SC route at 42 and 72 days of age. Blood samples were collected at 7, 14, 21, $28,35,42,49,56$ days after $1^{\text {st }}$ vaccination. The antibody titers in chicken of group A were ranged from 16 to 128 after first vaccination and 64 to 256 after second vaccination. The results of microplate agglutination tests for group A chicken is shown in Table 4.

Table 4. Microplate agglutination antibody titer of sera of chicken in group A vaccinated with AVIPro®109 SE4 following usual schedule of vaccination

\begin{tabular}{|c|c|c|c|c|c|c|c|c|c|c|c|}
\hline \multirow{2}{*}{$\begin{array}{c}\text { Age chicken } \\
\text { at } \\
1^{\text {st }} \\
\text { vaccination }\end{array}$} & \multirow[b]{2}{*}{$\begin{array}{c}2^{\text {nd }} \\
\text { vaccination }\end{array}$} & \multirow{2}{*}{$\begin{array}{l}\text { Tag. } \\
\text { No. }\end{array}$} & \multicolumn{9}{|c|}{ Serum antibody titer } \\
\hline & & & $\begin{array}{c}0 \\
\text { DPV } \\
\end{array}$ & $\begin{array}{c}7 \\
\text { DPV } \\
\end{array}$ & $\begin{array}{c}14 \\
\text { DPV }\end{array}$ & $\begin{array}{c}21 \\
\text { DPV }\end{array}$ & $\begin{array}{c}28 \\
\text { DPV }\end{array}$ & $\begin{array}{c}35 \\
\text { DPV }\end{array}$ & $\begin{array}{c}42 \\
\text { DPV }\end{array}$ & $\begin{array}{c}49 \\
\text { DPV }\end{array}$ & $\begin{array}{c}56 \\
\text { DPV } \\
\end{array}$ \\
\hline \multirow{5}{*}{42 days } & \multirow{5}{*}{72 days } & 1 & $\leq 4$ & 16 & 32 & 64 & 32 & 64 & 128 & 128 & 64 \\
\hline & & 2 & $\leq 4$ & 32 & 64 & 64 & 32 & 64 & 128 & 256 & 128 \\
\hline & & 3 & $\leq 4$ & 16 & 32 & 128 & 64 & 128 & 128 & 256 & 64 \\
\hline & & 4 & $\leq 4$ & 16 & 32 & 64 & 32 & 128 & 64 & 128 & 64 \\
\hline & & 5 & $\leq 4$ & 16 & 32 & 64 & 32 & 64 & 128 & 128 & 64 \\
\hline
\end{tabular}

$\mathrm{DPV}=$ Days post vaccination 


\section{Nasrin and others}

The mean \pm SE antibody titer in birds of group $\mathrm{A}$ after $1^{\text {st }}$ vaccination at $7,14,21,28$ days were $19.20 \pm 7.16, \quad 38.40 \pm 14.31, \quad 76.80 \pm 28.62$, $38.40 \pm 14.31$ respectively and after $2^{\text {nd }}$ dose at 35 , $42,49,56$ days $89.60 \pm 35.05,115.20 \pm 28.52$, $179.20 \pm 70.11$ and $76.80 \pm 28.62$ respectively. The highest antibody titer was obtained 179.20 \pm 70.11 at 21days after secondary vaccination, when the age of the birds was 93 days. The results shown in Table 6.
Microplate agglutination test of the sera of chicken in group $B$

$0.5 \mathrm{ml}$ of vaccine was administered to the chicken belonged to group B through SC route with the $1^{\text {st }}$ dose at 49 days and $2^{\text {nd }}$ dose at 79 days of age. Blood samples were collected at 7, 14, 21, 28, 35, $42,49,56$ days after $1^{\text {st }}$ vaccination. The antibody titer in the birds belonged to group B were ranged from 32 to 256 after first vaccination and 64 to 512 after second vaccination.

Table 5. Microplate agglutination antibody titer of sera of chicken in group B vaccinated with AVIPro ${ }^{109}$ SE4 using a newly suggested schedule of vaccination

\begin{tabular}{|c|c|c|c|c|c|c|c|c|c|c|c|}
\hline \multicolumn{2}{|c|}{ Age chicken at } & \multirow[b]{2}{*}{$\begin{array}{l}\text { Tag. } \\
\text { No. }\end{array}$} & \multicolumn{9}{|c|}{ Serum antibody titer } \\
\hline $\begin{array}{c}1^{\text {st }} \\
\text { vaccination }\end{array}$ & $\begin{array}{c}2^{\text {nd }} \\
\text { vaccination }\end{array}$ & & $\begin{array}{c}0 \\
\text { DPV }\end{array}$ & $7 \mathrm{DPV}$ & $\begin{array}{c}14 \\
\text { DPV }\end{array}$ & $\begin{array}{c}21 \\
\text { DPV }\end{array}$ & $\begin{array}{c}28 \\
\text { DPV }\end{array}$ & $\begin{array}{c}35 \\
\text { DPV }\end{array}$ & $\begin{array}{c}42 \\
\text { DPV }\end{array}$ & $\begin{array}{c}49 \\
\text { DPV }\end{array}$ & $\begin{array}{c}56 \\
\text { DPV } \\
\end{array}$ \\
\hline \multirow{5}{*}{49 days } & \multirow{5}{*}{79 days } & 1 & $\leq 4$ & 32 & 64 & 128 & 64 & 128 & 256 & 256 & 128 \\
\hline & & 2 & $\leq 4$ & 32 & 64 & 128 & 64 & 128 & 128 & 256 & 128 \\
\hline & & 3 & $\leq 4$ & 64 & 128 & 256 & 128 & 256 & 256 & 512 & 128 \\
\hline & & 4 & $\leq 4$ & 64 & 64 & 128 & 64 & 128 & 128 & 128 & 64 \\
\hline & & 5 & $\leq 4$ & 32 & 64 & 64 & 64 & 128 & 128 & 128 & 64 \\
\hline
\end{tabular}

DPV $=$ Days post vaccination

The mean \pm SE antibody titer in chicken of group $\mathrm{B}$ after $1^{\text {st }}$ dose at $7,14,21,28$ days were $44.80 \pm 17.53,76.80 \pm 28.62,140.80 \pm 70.11$ and $76.80 \pm 28.62$ respectively and after $2^{\text {nd }}$ dose at 35 , $42, \quad 49, \quad 56$ days were $153.60 \pm 57.24$,

$179.20 \pm 70.11,307.20 \pm 114.49$ and $102.40 \pm 35.05$ respectively. The highest antibody titer was obtained $307.20 \pm 114.49$ at 21 days after secondary vaccination, when the age of the birds was 100 days. The results are shown in Table 6.

Table 6. Mean \pm SE antibody titers of chicken belonged to group A, B and C

\begin{tabular}{cccccc}
\hline DPV & $\begin{array}{c}\text { Antibody titer } \\
\text { in unvaccinated } \\
\text { control } \\
\text { chickens }\end{array}$ & $\begin{array}{c}\text { Antibody titers } \\
\text { in chicken } \\
\text { belonged to } \\
\text { group A }\end{array}$ & $\begin{array}{c}\text { Antibody titers in } \\
\text { chicken belonged } \\
\text { to group B }\end{array}$ & $\begin{array}{c}\text { Level of } \\
\text { significance for } \\
\text { group A }\end{array}$ & $\begin{array}{c}\text { Level of } \\
\text { significance } \\
\text { for group B }\end{array}$ \\
\hline 7 & $\leq 4 \pm 0$ & $19.20 \pm 7.16$ & $44.80 \pm 17.53$ & $*$ & $*$ \\
14 & $\leq 4 \pm 0$ & $38.40 \pm 14.31$ & $76.80 \pm 28.62$ & $* *$ & $*$ \\
21 & $\leq 4 \pm 0$ & $76.80 \pm 28.62$ & $140.80 \pm 70.11$ & $*$ & $*$ \\
28 & $\leq 4 \pm 0$ & $38.40 \pm 14.31$ & $76.80 \pm 28.62$ & $* *$ & NS \\
35 & $\leq 4 \pm 0$ & $89.60 \pm 35.05$ & $153.60 \pm 57.24$ & $\mathrm{NS}$ & $*$ \\
42 & $\leq 4 \pm 0$ & $115.20 \pm 28.52$ & $179.20 \pm 70.11$ & $*$ & $* *$ \\
49 & $\leq 4 \pm 0$ & $179.20 \pm 70.11$ & $307.20 \pm 114.49$ & $\mathrm{NS}$ & $*$ \\
56 & $\leq 4 \pm 0$ & $76.80 \pm 28.62$ & $102.40 \pm 35.05$ & & $*$ \\
\hline
\end{tabular}

$* P<0.05, * *<0.01, \mathrm{NS}=P>0.05$

Five layer chicken in each of group A and B were vaccinated with AVIPro®109 SE4 vaccinefollowing usual and newly suggested schedule respectively. $1^{\text {st }}$ dose of vaccine was administered at 42 and 49 days of age respectively in group $\mathrm{A}$ and $\mathrm{B}$ and $2^{\text {nd }}$ dose was administered at 72 and 79 days of age respectively. Blood samples were collected from each group at 7, 14, 21, 28 after $1^{\text {st }}$ dose and 35, $42,49,56$ days after $2^{\text {nd }}$ dose. The comparative results of post vaccination antibody titer of chicken in group A and B vaccinated with AVIPro®109 SE4 vaccine revealed that the highest post secondary vaccination titer of 
$179.20 \pm 70.11$ at 21 days in group $\mathrm{A}$ and $307.20 \pm 114.49$ in group B at 21 days after secondary vaccination.

\section{Discussion}

Slide agglutination test was performed for the detection of antibody against $S$. enteritidis vaccine (AVI Pro®109SE4) in sera of vaccinated and unvaccinated birds. Sera of all vaccinated birds showed positive agglutination reaction but sera of non-vaccinated control birds did not agglutinate. Buxton and Davies (1963), Rahman et al., (2005) also performed slide agglutination test against $S$. gallinarum. Following this method detection of antibodies against $S$. enteritidis and revealed the same result.

Microplate agglutination test was conducted to determine the antibody titer of the sera of vaccinated and unvaccinated chicken infected with S.enteritidis as per the method described by schlink et al., (1979). This microplate agglutination test was also applied by Wambura et al., (2006), Rahman et al., (2005) and Iotova (1982) to assay antibodies against $S$. gallinarum. Given positive result.

The pre-vaccination antibody titer of sera of all vaccinated and unvaccinated control birds were recorded as $\leq 4$. The primary vaccination induced rise of antibody which ranged from 16 to 128after first vaccination and 64 to 256 after second vaccination in birds belonged to group $\mathrm{A}$. The antibody titers obtained from group B were ranged from 32 to 256 after first vaccination and 128 to 512 after second vaccination. The antibody titer induced by primary vaccination reached to a peak, which declined gradually thereafter. A similar finding was also reported by Bhattacharya et al., (2004) against S. gallinarum. The author observed that the antibody titer induced by primary vaccination first reached to a peak, which declined gradually thereafter.

In this study administration of booster vaccine further induced rise of antibody titer. In group A and $\mathrm{B}$ the highest post secondary vaccination antibody titer ranged from 128 to 256 and 256 to 512 was obtained at 21 days after booster vaccination. Then the titer started to decline. The lowest antibody titer ranged from 64 to 128 and 64 to 128 was recorded 72 and 79 days post vaccination, respectively.

The mean \pm SE antibody titers of birds of group A at $7,14,21,28$ days after primary vaccination were $19.20 \pm 7.16,38.40 \pm 14.31,76.80 \pm 28.62$ and $38.40 \pm 14.31$ respectively. Antibody titers after booster vaccination were recorded at $35,42,49$ and 56 days as $89.60 \pm 35.05,115.20 \pm 28.52$, $179.20 \pm 70.11$ and $76.80 \pm 28.62$, respectively. In group A the highest antibody titer was recorded as $179.20 \pm 70.11$ at 21 days after secondary vaccination, when the age of the birds was 93 days.

In the present study the mean antibody titers of bird belonged to group $\mathrm{B} 1^{\text {st }}$ dose were $44.80 \pm 17.53, \quad 76.80 \pm 28.62, \quad 140.80 \pm 70.11$ and $76.80 \pm 28.62$ at $7,14,21$ and 28 days after primary vaccination respectively. Mean antibody titers $35,42,49,56$ days were $153.60 \pm 57.24$, $179.20 \pm 70.11,307.20 \pm 114.49$ and $102.40 \pm 35.05$ at $35,42,49,56$ days respectivelyafter booster vaccination. In group $B$ the highest antibody titer was $307.20 \pm 114.49$ at 21 days after booster vaccination.

Data of this study indicated that vaccination of chicken at 49 days of age induced better immune response as compared to vaccination at 42 days of age. Vodas (1978) also stated that agglutination formation against $S$. gallinarum in chicken was directly correlated with age. The increased amount of antibody recorded in birds of group B as compared to group $\mathrm{A}$ in this study might be associated $\cdot$ with age of birds. This study recorded higher antibody titer in chickens of group A and B vaccinated with Salmonella enteritidis vaccine (AVI Pro®109SE4). The induction of higher degree of immunity by vaccine (AVI Pro®109SE4) might be due to higher immunogenic character of the vaccine strain. There were several limitations of this study such as antibody titers could not determined by ELISA.The sample size was not large, Short study period as well immune response of vaccine was not studied through various routes. 
Moreover, the tentatively (cultural, biochemical, serological test) identified $S$. enteritidis was used as antigen in case of slide and microplate agglutination test. However, for confirming identification and characterization of this isolated organism needs further molecular characterization.

\section{Conclusions}

The results of the study indicate that booster vaccination induce better immunity in aged layer birds. It can also be concluded thatAVI Pro®109SE4 vaccine successfully induced a good level of antibody in experiment layer birds. Both usual and a newly suggested schedule of vaccination with AVI Pro®109SE4 vaccine induced significant level of antibody production which might be able to confer protection against Salmonella enteritidis infection. Finally, AVI Pro®109SE4 vaccine can be used to control Salmonella enteritidis infection of chicken in Bangladesh.

\section{Acknowledgement}

Not applicable.

\section{Funding}

The vaccine was supported by the ACI Bangladesh Limited. The chemicals and samples were brought by self finance for completion of MS thesis.

\section{Competing interest}

Nothing to declare.

\section{References}

1. Bhattacharyya DK, Rahman H, Murugkar HV. Development and evaluation of Salmonella toxoid vaccine for poultry. Indian Journal of Animal Science. 2004; 74(6): 58 1-585.

2. Buxton A, Davies JM. Use of bacterial agglutination and antiglobulin HA test to detect antibody against $S$. gallinarum. Immunology. 1963; 6(1): 530-538.

3. Calnek BW, Barnes HJ, Beard CW, McDougald LR, Saif YM. Diseases of poultry. $10^{\text {th }}$ edition. Iowa State University Press, Ames, Iowa. 1997; 88-89.
4. Choudhury KA, Amin MM, Rahman A and Ali MR. Investigation of natural outbreak of fowl cholera. Bangladesh veterinary Journal. (1985)19(1-4):49-56.

5. Iotova I. Phagocytic activity and antibody formation in relation to the resistance of fowls to $S$. gallinarum infection. Veterinarno Meditsinski Nauki. 1982;19(9): 52-60.

6. Pomery BS. In Hofstad, M. S.; Calnek, B. W.; Helmboldt, C. F.; Reid, W. M. and Yoder, Jr. H. W. (eds.). Diseases of Poultry, 7th edition. Iowa State University. Press, Ames. 1978; 79-83.

7. Rahman MM, Khan ZUM, Rashid SMH. Evaluation of the efficacy of a bacterin against Salmonella gallinarum infection. Journal of Animal Veterinary Advances 2005; 4(3): 332-334.

8. Raul I, Clavijo C, Loui GL, Andersen LW, Sangwei LU. Identification of genes associated with survival of Salmonella enterica serovar enteritidis in chicken egg albumen. Avian Diseases. 2005; 3(12): 8286.

9. Schlink GT, Olson LD. A Microtiter Agglutination Test for Anti Pasteurella multocida antibodies in turkeys. Avian Diseases. 1979; 23: 1066-1071. 10. Shil RN, Debnath SC. An introduction to the Theory of Statistics. First edn. City Press. Mymensingh, Bangladesh. 1985; 3235

11. Vodas K. Correlation of agglutinin production with age in fowls experimentally infected with Salmonella gallinarum. Veterinary Bulletin 1978; 48(2): 758.

12. Wambura PN, Makuri HG, Hoza AS, Tuntufye H, Mellau LSB. Application of micro agglutination test for detection of antibodies to Salmonella gallinarum in commercial layer chickens. Bulletin of Animal Health and Production in Africa. 2006; 54(2): 124-130.

13. Zhang-Barber L, Turner AK, Barrow PA. Vaccination for control of salmonella inpoultry. Vaccine. 1999; 17: 2538-2545. 